\title{
Efektivitas Pendekatan Ego Untuk Meningkatkan Resiliensi Diri Siswa di SMAN 2 Padang Panjang
}

\author{
Wilda Hafiva \\ Institut Agama Islam Negeri (IAIN) Bukittiggi \\ wildahafiva280797@gmail.com \\ Fadhilla Yusri \\ Institut Agama Islam Negeri (IAIN) Bukittiggi \\ Wedra Aprison \\ Institut Agama Islam Negeri (IAIN) Bukittiggi
}

\begin{abstract}
The purpose of this study was to determine the increase in student self-resilience through ego approach group counseling services. This type of research is quantitative experiments. The research data were obtained through a Likert scale student resilience research instrument with five alternative answers. The research design used was One Group Pretest-Postest Design. The instrument validity was tested using the Product Moment formula, and the reliability test was performed using the Alpha formula. The instrument validity test results obtained valid instrument items 52 items and 13 items are invalid with a reliability coefficient of 0.951 . Based on the results of the analysis of research data after getting treatment of the ego approach group counseling services, there was an increase in self-resilience of students of class XI MIPA through ego approach group counseling services. From the results of proposing a hypothesis using the z-test formula, the value of Zhitung 2,807, while ztable is 1,833 , it can be concluded that "group approach counseling services ego can increase student self-resilience". From the results of this study it is suggested that the supervising teacher should program an ego approach group counseling service so that students can increase self-resilience.
\end{abstract}

Key Words: Ego Approach Group Counseling, Resilience 


\begin{abstract}
Abstrak
Tujuan penelitian ini untuk mengetahui peningkatan resiliensi diri siswa melalui layanan konseling kelompok pendekatan ego. Jenis penelitian adalah kuantitatif eksperimen. Data penelitian diperoleh melalui instrument penelitian skala Likert resiliensi diri siswa dengan lima alternatif jawaban. Desain penelitian yang digunakan adalah One Group Pretest-Postest Design. Uji validitas instrument mengunakan rumus Product Moment, dan dilakukan uji reliabelitas menggunakan rumus Alpha. Hasil uji validitas instrument diperoleh butir instrument yang valid 52 butir dan 13 butir tidak valid dengan koefesien reliabelitas sebesar 0,951. Berdasarkan hasil analisis data penelitian setelah mendapatkan perlakuan layanan konseling kelompok pendekatan ego, menunjukkan adanya peningkatan resiliensi diri siswa kelas XI MIPA melalui layanan konseling kelompok pendekatan ego. Dari hasil pengajuan hipotesis menggunakan rumus z-test diperoleh nilai Zhitung 2.807 sementara ztabel yaitu 1.833, maka dapat disimpulkan bahwa "layanan konseling kelompok pendekatan ego dapat meningkatkan resiliensi diri siswa.". Dari hasil penelitian ini di sarankan kepada guru pembimbing hendaknya perlu memprogramkan layanan konseling kelompok pendekatan ego agar siswa dapat meningkatkan resiliensi diri.
\end{abstract}

Kata Kunci: Konseling Kelompok Pendekatan Ego, Resiliensi

\title{
Pendahuluan
}

Siswa adalah manusia yang memiliki potensi yang dapat dikembangkan melalui pendidikan, baik pendidikan formal maupun non formal, melalui proses belajar siswa memperoleh ilmu dan wawasan baru yang berguna bagi kehidupan siswa. Salah satu lembaga formal tempat siswa belajar adalah lembaga pendidikan sekolah. Hal ini tercantum dalam Undang-undang No. 20 Tahun 2003 pasal 1 ayat 1 tentang sistem pendidikan Nasional, dijelaskan bahwa pendidikan adalah usaha sadar dan terencana untuk mewujudkan suasana belajar dan proses pembelajaran agar peserta didik secara aktif mengembangkan potensi dirinya untuk memiliki kekuatan spiritual keagamaan, pengendalian diri, kepribadian, kecerdasan, akhlak mulia, serta keterampilan yang diperlukan dirinya, masyarakat, bangsa dan negara. ${ }^{1}$ Ini menggambarkan bahwa pendidikan dapat mengembangkan potensi diri, memiliki kekuatan spiritual keagamaan, pengendalian diri, kepribadian, kecerdasan, akhlak mulia, serta keterampilan 
yang diperlukan, tentunya dalam hal ini juga diperlukan kerjasama dari berbagai pihak dalam membantu peserta didik, terutama dalam proses belajar.

Belajar merupakan faktor penting dalam kehidupan remaja, apalagi pada usia sekolah. Melalui belajar siswa memperoleh wawasan dan pengetahuan yang tidak diketahui sebelumnya. Jadi melalui proses belajar individu memperoleh pemahaman dan wawasan baru. Tidak hanya memperoleh pemahaman dan wawasan baru, pada saat sekarang ini perubahan-perubahan yang terjadi sangat cepat dan tidak jarang menimbulkan dampak yang tidak menyenangkan bagi remaja. Dalam hal ini, resiliensi dianggap sebagai kemampuan yang mempunyai kekuatan besar untuk mengatasi berbagai kesulitan dan dampak yang tidak menyenangkan yang dihadapi siswa.

Istilah resiliensi diformulasikan pertama kali oleh Block dengan seperti yang dijelaskan oleh Klohnen dengan nama "ego-resilience", yang diartikan sebagai kemampuan umum yang melibatkan kemampuan penyesuaian diri yang tinggi dan luwes saat dihadapkan pada tekanan internal maupun eksternal. ${ }^{2}$ Resiliensi berasal dari bahasa latin "resilire" yang artinya melambung kembali. Menurut Desmita resiliensi adalah kemampuan atau kapasitas insan yang dimiliki seseorang, kelompok atau masyarakat yang memungkinkannya untuk menghadapi, mencegah, meminimalkan dan bahkan menghilangkan dampakdampak yang merugikan dari kondisi-kondisi yang tidak menyenangkan, atau bahkan mengubah kondisi kehidupan yang menyengsarakan menjadi suatu hal yang wajar untuk diatasi. ${ }^{3}$

286:

Istilah resiliensi juga terdapat dalam Al-Qur'an surat Al-Baqarah ayat

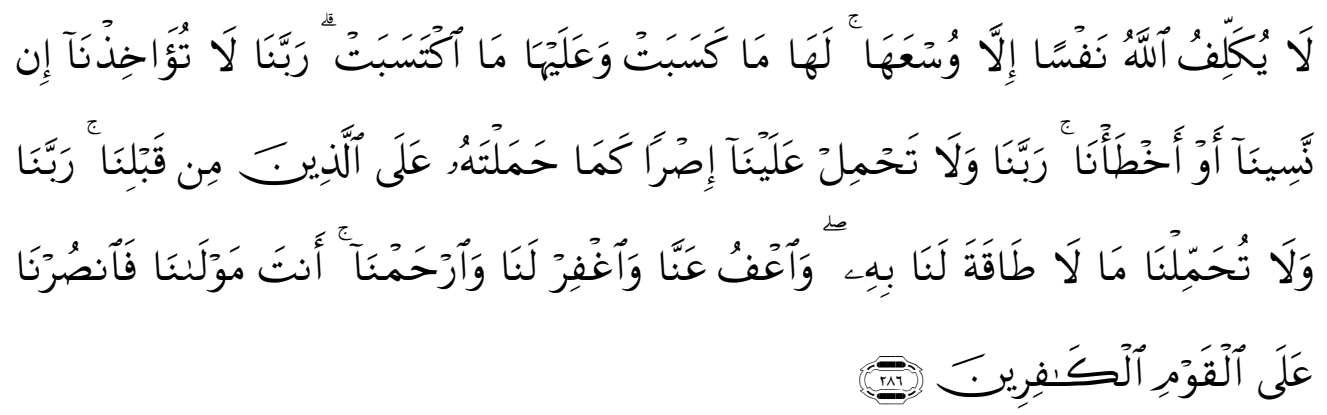

Allah tidak membebani seseorang melainkan sesuai dengan kesanggupannya. ia mendapat pahala (dari kebajikan) yang diusabakannya dan ia mendapat siksa (dari kejahatan) yang dikerjakannya. (mereka berdoa): "Ya Tuban Kami, janganlab Engkan bukum Kami jika Kami lupa atau Kami tersalah. Ya Tuban Kami, janganlah Engkau bebankan kepada

${ }^{2}$ Hendriani, W. (2018). Resiliensi psikologis: sebuab pengantar. Kencana.

${ }^{3}$ Desmita, Psikologi Perkembangan, (Bandung: PT. Remaja Rosda Karya, 2006), Cet. 2, hlm. 228. 
Kami beban yang berat sebagaimana Engkau bebankan kepada orang-orang sebelum kami. Ya Tuban Kami, janganlah Engkau pikulkan kepada Kami apa yang tak sanggup Kami memikulnya. beri ma'aflah kami; ampunilah kami; dan rabmatilah kami. Engkaulah penolong Kami, Maka tolonglah Kami terhadap kaum yang kafir."

Firman Allah SWT dalam surat Al-Baqarah ayat 286 dapat ditarik kesimpulan bahwa Allah SWT tidak akan membebani suatu permasalahan di luar batas kemampuan setiap manusia itu sendiri. Permasalahan yang dihadapi oleh manusia walaupun dianggap berat, namun semua itu akan mampu dihadapi jika manusia melakukan yang terbaik dan mampu untuk menyesuaikan diri dengan masalah tersebut dengan baik.

Dari pendapat di atas dapat disimpulkan bahwa resiliensi merupakan kemampuan yang dimiliki oleh individu, kelompok atau masyarakat untuk menghadapi, mencegah, mengatasi, meminimalkan, bahkan menghilangkan dampak-dampak yang merugikan serta mengganggu yang menjadikan individu berada dalam keadaan tertekan baik itu tekanan dari luar maupun tekanan dari dalam, kemudian individu itu mampu menyesuaikan diri serta mengubah kondisi kehidupan yang menyengsarakan menjadi suatu hal yang wajar untuk diatasi dan bangkit kembali dari kemunduran.

Terdapat tiga faktor yang menyusun resiliensi pada diri seseorang, yaitu dukungan eksternal (external support), dukungan internal Iinternal support), beserta dukungan sosial (social support). berdasarkan ketiga faktor ini, seorang remaja yang resilien dapat dicirikan dengan adanya hubungan yang dapat dipercaya antara dirinya dengan orang-orang disekitarnya, adanya struktur dan atan di rumah yang menjadikannya mampu mebedakan hal-hal yang baik dn yang buruk, serta adanya dorongan dari orang-orang sekitar untuk menjadikan dirinya sebagai seseorang yang mandiri. Selain itu, remaja yang resilienjuga memiliki kemandirian, rasa dicintai oleh lingkungan disekitarnya dan rasa tanggung jawab atau setiap hal yang dilakukannya. Selanjutnya, kemampuan komunikasi dan penyelesaian masalah juga merupakan ciri-ciri yng dimiliki oleh seorang remaja yang resilien. ${ }^{4}$

Ketiga faktor tersebut sangat mempengaruhi bagaimana terbentuknya resiliensi diri, hal ini tergantung oleh diri seseorang bagaimana tindakan atau sikap yang akan ditampilkan untuk mengatasi permasalahan yang terjadi. Bimbingan dan konseling berperan untuk membantu siswa dalam mengentaskan permasalahan yang berhubungan dengan resiliensi, salah satu layanan bimbingan dan konseling adalah layanan konseling kelompok yang berguna bagi pengembangan, pribadi dan atau pemecahan masalah individu yang menjadi peserta kegiatan kelompok.

\footnotetext{
${ }^{4}$ Narendra, Dimas Reza, 2017, The Effect of Five Factor Model Ofpersonality and Religiosity Toward Adolescent's Resilience Whoose Parents are Divorced. Vol. VI No. 1 Januari 2017.
} 
Konseling kelompok (KKp) pada dasarnya adalah layanan konseling perorangan yang dilaksanakan di dalam suasana kelompok. Di sana ada konselor (yang jumlahnya mungkin lebih dari seorang) dan ada klien, yaitu para anggota kelompok (yang jumlahnya paling kurang dua orang). ${ }^{5}$ Pembahasan masalah dalam konseling kelompok ini bersifat mendalam, menyentuh hal penting tentang diri klien, bersifat meluas meliputi berbagai sisi yang menyangkut dengan permasalahan klien akan tetapi juga bersifat spesifik menuju ke arah pengentasan masalah. Konseling kelompok yang dimaksud adalah sama seperti konseling perorangan, yaitu hangat, terbuka, permisif dan penuh keakraban. Di mana juga ada pengungkapan dan permasalahan klien, penelusuran sebab-sebab timbulnya masalah, upaya pemecahan masalah, kegiatan evaluasi dan tindak lanjut dalam konseling ego.

Konseling ego dipopulerkan oleh Erikson. Konseling ego memiliki ciri khas yang lebih menekankan pada fungsi ego. Kegiatan konseling yang dilakukan pada umumnya bertujuan untuk memperkuat ego strenght, yang berarti melatih kekuatan ego klien. Seringkali orang yang bermasalah adalah orang yang memiliki ego yang lemah. Misalnya, orang yang rendah diri, dan tidak bisa mengambil keputusan secara tepat dikarenakan ia tidak mampu memfungsikan egonya secara penuh, baik untuk memenuhi kebutuhan hidupnya, meraih keinginannya. ${ }^{6}$ Konseling ego sangat dibutuhkan oleh setiap individu yang ingin hidupnya menjadi sukses, agar individu tersebut mampu memaksimalkan anugerah yang telah Allah SWT berikan itu untuk menimbang dan memikirkan keputusan ataupun solusi dari permasalahan hidup yang mereka alami, sehingga hidup terasa nyaman dan berjalan dengan baik.

Agar individu tersebut tidak terlalu larut dalam permasalahannya, maka yang dapat dilakukan konselor menurut konego adalah, membina hubungan akrab dengan klien. Setelah terbina keakraban yang baik antara konselor dan klien, klienpun sudah merasa nyaman bersama dengan konselor. Maka hal berikutnya yang perlu diperbaiki oleh konselor adalah membentuk coping behavior yang dikehendaki sesuai dengan lingkungan dan situasi. Kemudian membantu memfungsikan ego klien kembali sebagaimana semestinya. ${ }^{7}$

Istilah resiliensi pertama kali diformulasikan dengan nama ego-resilience yang berarti kemampuan umum yang melibatkan kemampuan penyesuaian diri yang tinggi dan luwes saat dihadapkan pada tekanan internal maupun eksternal, untuk itu pelayanan konseling yang diberikan dapat dengan menggunakan pendekatan konseling ego. Menurut Taufik, konseling-ego merupakan

\footnotetext{
${ }^{5}$ Prayitno, Dasar-dasar Bimbingan dan Konseling, (Jakarta: Rineka Cipta, 1999), hlm. 311.

${ }^{6}$ Novi Hendri, Model-model Konseling, (Medan: Perdana Mulya Sarana 2013), hlm 169.

7 Yusri, F. (2014). Pemanfaatan Model-model dalam Pelayanan Konseling untuk Membentuk Generasi Berkarakter Bebas Narkoba. Jurnal Konseling dan Pendidikan, 2(3), 17-30.
} 
pendekatan konseling yang lebih menekankan pada fungsi ego. ${ }^{8}$ Maksudnya adalah bagaimana siswa yang menjadi sasaran layanan nantinya dapat memperkuat ego resiliennya karena dalam konseling-ego dikenal sebuah istilah dengan sebutan "ego strength" yang artinya kekuatan ego. Ego dalam konselingego mempunyai tiga fungsi yaitunya:

1. Impulse economic (imec) yaitu kemampuan ego untuk tidak hanya mengontrol dorongan-dorongan, tetapi menyalurkannya ke arah tingkah laku yang lebih dapat diterima dan berguna.

2. Cognitive function (cogfun) yaitu kemampuan ego untuk menganalisis dan berfikir logis mengatasi perasaan (kemampuan ego yang bebas dari pengaruh id)

3. Controlling function (confun) yaitu kemampuan ego untuk memusatkan usaha penyelesaian tugas tanpa diganggu oleh perasaan.

Berdasarkan kutipan di atas ego mempunyai tiga fungsi yaitunya fungsi dorongan ekonomis, fungsi kognitif dan fungsi pengawasan. Ketiga fungsi ego ini sangat menentukan kuat lemahnya ego seseorang. Konseling-ego memandang individu yang bermasalah adalah individu yang memiliki ego yang lemah. Menurut Prayitno, lemah atau kurang kuatnya ego seseorang disebabkan oleh beberapa hal, yaitu individu kurang mampu merespon dengan cara yang layak, pola tingkah laku yang dimiliki tidak cocok lagi dengan tuntutan lingkungan (situasi) dan rusaknya fungsi ego. ${ }^{10}$ Individu yang kurang kuat egonya adalah karena individu tersebut tidak dapat memfungsikan egonya secara penuh, baik untuk menggerakkan dirinya dalam memenuhi kebutuhan-kebutuhannya maupun untuk meraih keinginan-keinginannya.

Penelitian bertujuan ini untuk mengetahui peningkatan resiliensi diri siswa melalui layanan konseling kelompok pendekatan ego. Jenis penelitian adalah kuantitatif eksperimen. Data penelitian diperoleh melalui instrument penelitian skala Likert resiliensi diri siswa dengan lima alternatif jawaban. Desain penelitian yang digunakan adalah One Group Pretest-Postest Design. Uji validitas instrument mengunakan rumus Product Moment, dan dilakukan uji reliabelitas menggunakan rumus Alpha.

\section{Hasil dan Pembahasan}

\section{Hasil Pretest dan Postest}

Bentuk konseling kelompok pendekatan ego ini adalah konseling kelompok melalui pendekatan ego untuk meningkatkan resiliensi diri siswa. Adapu hasil pretest dan postest resiliensi diri sebagaimana tabel 1 berikut :

\footnotetext{
${ }^{8}$ Taufik, Model-Model Konseling, (Padang: FKIP UNP, 2009), hlm. 65.

${ }_{9}$ Prayitno, Konseling Pancawaskita (Kerangka Konseling Eklektik), (Padang: FKIP UNP, 1998), hlm. 46.

${ }^{10}$ Prayitno, Konseling..., hlm. 47.
} 
Tabel 1

Hasil Pretest dan Postest Resiliensi Diri

\begin{tabular}{|c|c|c|c|c|c|}
\hline \multirow[b]{2}{*}{ No } & \multirow[b]{2}{*}{ Identitas } & \multicolumn{2}{|c|}{ Pretest } & \multicolumn{2}{|c|}{ Postest } \\
\hline & & Skor & Kategori & Skor & Kategori \\
\hline 1 & FG & 170 & Sedang & 181 & Tinggi \\
\hline 2 & AA & 169 & Sedang & 186 & Tinggi \\
\hline 3 & SA & 167 & Sedang & 186 & Tinggi \\
\hline 4 & AFI & 169 & Sedang & 195 & Tinggi \\
\hline 5 & DF & 161 & Sedang & 195 & Tinggi \\
\hline 6 & TH & 162 & Sedang & 180 & Tinggi \\
\hline 7 & $\mathrm{BBC}$ & 158 & Sedang & 180 & Tinggi \\
\hline 8 & $\mathrm{KF}$ & 159 & Sedang & 178 & Sedang \\
\hline 9 & PP & 154 & Sedang & 162 & Sedang \\
\hline 10 & $\mathrm{KDA}$ & 158 & Sedang & 176 & Sedang \\
\hline & $\begin{array}{l}\text { Skor } \\
\text { keseuruhan }\end{array}$ & 1.627 & & 1.819 & \\
\hline & Rata-rata skor & 163 & Sedang & 182 & Tinggi \\
\hline
\end{tabular}

Berdasarkan tabel hasil pretest dan posttest diatas, terlihat jelas terdapat penurunan skor resiensi diri siswa yang memiliki rata-rata skor sedang menjadi tinggi, hal ini terjadi setelah diberikan perlakuan (treatment). Secara umum semua objek penelitian mengalami peningkatan skor. Untuk lebih jelasnya dapat juga dilihat dari diagram dibawah ini:

\section{Gambar 1}

\section{Diagram Perbedaan Hasil Pretest dan Posttest}

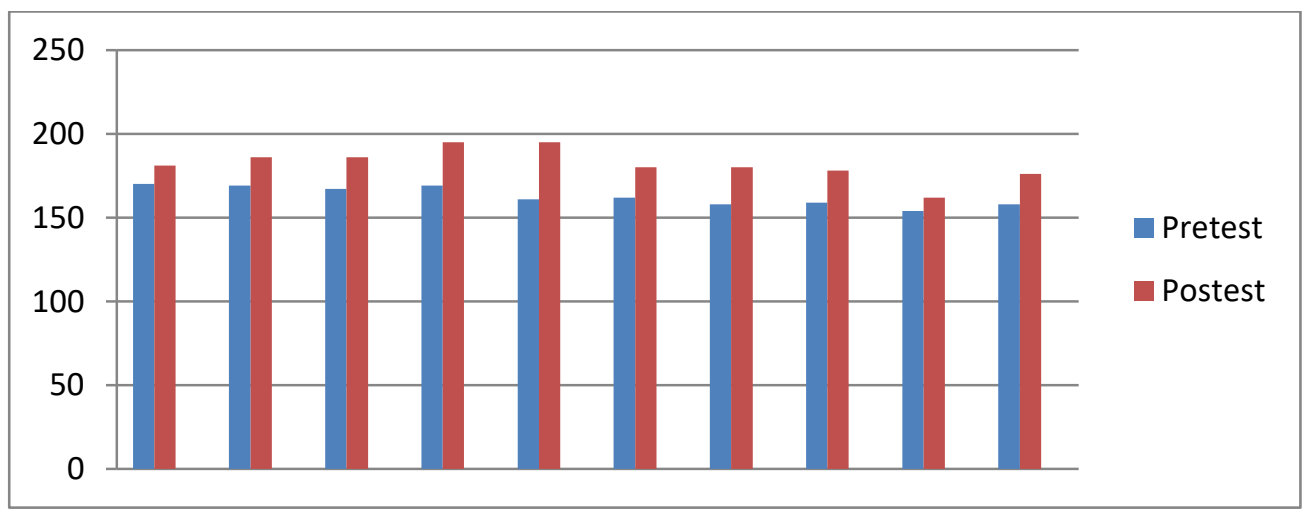

Maka dapat disimpulkan dari diagram diatas, bahwa rata-rata skor postest mengalami penurunan terhadap resiiensi diri setelah diberikan pendekatan ego. Perbedaan pretest dan posttest dari hasil rata-rata dapat dilihat pada tabel 2 di bawah ini: 


\section{Tabel 2}

\section{Gambaran Hasil Rata-rata Pretest dan Postest}

Tabel di atas menunjukkan bahwa hasil pretest dan postest berdasarkan dari analisis statistik meggunakan SPSS. Adapun persentase yang di dapat dari hasil rata-rata pretest dan postest yaitu sebesar 80\%. Artinya persentase efektivitas pendekatan ego untuk meningkakan resiliensi diri siswa di SMAN 2 Padang Panjang sebesar 80\% dalam kategori tinggi.

1. Perbedaan Hasil Pretest dan Postest Resiliensi Diri Siswa

Perbedaan frekuensi tingkat resiliensi diri siswa untuk masing-masing kategori dari hasil pretest dan postest dapat dilihat pada tabel 3 berikut:

Tabel 3

Distribusi frekuensi Skor Pretest dan Postest Resiliensi Diri Siswa

\begin{tabular}{|l|l|l|l|l|l|}
\hline \multirow{2}{*}{ Skor } & \multirow{2}{*}{ Kategori } & Pretest & \multicolumn{2}{l|}{ Postest } \\
\cline { 3 - 6 } & F & $\%$ & F & $\%$ \\
\hline$>189$ & Sangat Tinggi & 0 & 0 & 2 & 0 \\
\hline $151-188$ & Tinggi & 10 & 100 & 8 & 70 \\
\hline $113-150$ & Sedang & 0 & 0 & 0 & 30 \\
\hline $75-112$ & Rendah & 0 & 0 & 0 & 0 \\
\hline$<74$ & Sangat Rendah & 0 & 0 & 0 & 0 \\
\hline Jumlah & 10 & 100 & 10 & 100 \\
\hline
\end{tabular}

Berdasarkan tabel di atas dapat diketahui bahwa pada hasil pretest terdapat 10 frekuensi dalam kategori sangat sedang. Sedangkan dalam hasil postest terdapat 7 frekuensi dalam kategori tinggi dan 3 frekuensi dalam kategori sedang. Secara keseluruhan hasil pretest dan postest dalam distribusi frekuensi menunjukkan 100\%.

Hasil dari suatu hipotesis dikatakan berhasil jika nilai Sig. (2-tailed) < 0,05 maka terdapat perbedaan yang signifikan antara hasil pretest dan postest serta ha diterima dan ho ditolak, dan sebaliknya apabila nilai Asymp. Sig.(2tailed) $>0,05$ maka tidak terdapat perbedaan yang signifikan antara hasil pretest dan postest serta ho diterima dan ha ditolak. Pengolahan data ini memakai program SPSS versi 22. 
Tabel 4

Uji Wilcoxon

Ranks

\begin{tabular}{|ll|l|l|l|}
\hline & N & Mean Rank & Sum of Ranks \\
\hline Postest - Pretest & Negative Ranks & $0 \mathrm{a}$ & 00 &, 00 \\
& Positive Ranks & $10 \mathrm{~b}$ & 5,50 & 55,00 \\
& Ties & $0 \mathrm{c}$ & & \\
& Total & 10 & & \\
\hline
\end{tabular}

a. Postest $<$ Pretest

b. Postest $>$ Pretest

c. Postest $=$ Pretest

Tabel di atas menunjukkan bahwa negative rank atau selisih negatif antara hasil peningkatan resiliensi pretest dan posttest adalah 0 data negatif artinya terdapat 0 orang siswa yang mengalami peningkatan resiliensi pretest dan posttest. Disini terdapat 10 data positif $(\mathrm{N})$ artinya terdapat peningkatan resiliensi, mean of rank sebesar 5,50 sedangakan Sum of Rank sebesar 55,00. Ties adalah kesamaan nilai pretest dan nilai posttest, disini ties adalah 0 sehingga dapat dikatakan bahwa tidak terdapat nilai yang sama antara pretest dan posttest. Dari penjelasan di atas dapat dikatakan bahwa terdapat peningkatan resiliensi. Tabel 5

Test Statisticsa

\begin{tabular}{|l|l|}
\hline & $\begin{array}{l}\text { Postest } \\
\text { Pretest }\end{array}$ \\
\hline$Z$ & $2,807 \mathrm{~b}$ \\
Asymp. Sig. (2-tailed) &, 005 \\
\hline
\end{tabular}

a. Wilcoxon Signed Ranks Test

b. Based on negative ranks.

Berdasarkan tabel di atas dapat diketahui bahwa terdapat perbedaan antara nilai pretest dengan nilai posttest, hal ini dibuktikan dengan nilai zhitung sebesar 2,807 sementara tabel sebesar 1,833 yang berarti lebih kecil dari zhitung pada taraf signifikan 0,05. Maka dapat diketahui zhitung > ztabel yaitu 2,807 > 1,833 sehingga ada perbedaan rata-rata nilai tes antara sebelum dan setelah diberikan perlakuan kepada siswa yang memiliki resiliensi yang rendah sehingga Ha diterima dan Ho ditolak. Sedangkan berdasar dari hasil asymp sig (2-tailed) diperoleh nilai sebesar $(0,005)$ yang berarti lebih kecil dari alpha $(0,05)$. Maka dapat dikatakan $\mathrm{Ha}$ diterima artinya terdapat peningkatan resiliensi diri untuk pretest dan posttest, sehingga dapat dikatakan bahwa konseling kelompok dengan pendekatan ego efektif untuk meningkatkan resiliensi diri siswa di SMAN 2 Padang Panjang. 
Hasil pengolahan data pada 10 orang sampel diketahui bahwa hasil pretest meanya adalah 135,30 , mediannya adalah 164 , variannya adalah 62,456 yaitu varian data yang di dapat dari kelipatan standar deviasi, sedangkan nilai maximum dalam kelompok ini adalah 155 dan nilai minimum adalah 125, standar deviasinya 7,903 adalah ukuran penyebaran data dari rata-ratanya. Maka dapat dikatakan bahwa rata-rata skor kelompok pretest tergolong pada kategori sedang untuk resiliensi diri. Artinya masih terdapat beberapa hal terkait resiliensi diri yang belum dimiliki oleh siswa di SMAN 2 Padang Panjang.

Hasil pengolahan data diketahui bahawa postest dengan jumlah sampel 10 orang, meanya adalah 136,10, mediannya adalah 134, variannya adalah 111,656 yaitu varian data yang di dapat dari kelipatan standar deviasi, sedangkan nilai maximum dalam kelompok ini adalah 155 dan nilai minimum adalah 125 , standar deviasinya 10,567 adalah ukuran penyebaran data dari rata-ratanya. Ratarata skor kelompok postest tergolong pada kategori tinggi untuk resiliensi diri. Artinya terdapat peningkatan dari beberapa hal terkait resiliensi diri yang dimiliki oleh siswa di SMAN 2 Padang Panjang.

Hasil uji Wilcoxon menunjukkan bahwa negative rank atau selisih negatif anatara hasil resiliensi diri untuk pretest dan postest adalah 0 pada nilai $\mathrm{N}, 00$ pada mean rank dan ,00 pada sum of ranks. Nilai ini menunjukkan tidak adanya baik penigkatan atau penurunan dari nilai pretest dan postest. Sedangkan Positif Rank atau selisih positif antara resiliensi diri pretest dan postest. Terdapat 10 data positif $(\mathrm{N})$ yang artinya ada 10 orang siswa yang mengalami peningkatan pada resiliensi diri dari nilai pretest ke nilai postest. Mean rank atau rata-rata peningkatan tersebut adalah 5,50. Sedangkan sum of ranks adalah sebesar 55,00. Ties adalah kesamaan nilai pretest dan nilai postest, di sini ties adalah 0 sehingga dapat dikatakan bahwa tidak ada nilai yang sama antara pretest dan nilai postest. Dari penjelasan diatas dapat disimpulkan bahwa trdapat peningkatan resiliensi diri siswa di SMAN 2 Padang Panjang.

Konsep resiliensi disadari oleh kapasitas kemampuan individu untuk menerima, mengahadapi dan mentransformasikan masalah-masalah yang telah, sedang dan akan dihadapi sepanjang kehidupan individu. Upaya untuk membantu siswa yang memilki resiliensi diri rendah diperlukan dengan layanan konseling kelompok. Menurut Prayitno layanan konseling kelompok merupakan layanan konseling yang diselenggarakan dalam suasana kelompok, yang memungkinkan siswa memperoleh kesempatan bagi pembahasan dan pengentasan masalah yang dialami melalui dinamika kelompok. Pelaksanaan konseling kelompok dapat membantu siswa yang tengah mengalami kesulitan mengatasi kondisi stres yang ditimbulkan karena adanya tantangan kehidupan. ${ }^{11}$

11 Qurrotul Ainiah, Jurnal Mahasiswa Bimbingan dan Konseling Penerapan Konseling Kelompok Realita untuk Meningkatkan Resiliensi Diri (Self Resilience) Siswa, diakses pada tanggal 02 Januari 2020. 
Menurut Dewa Ketut Sukardi tujuan konseling kelompok adalah pertama, melatih anggota kelompok agar berani berbicara dengan orang banyak. Kedua, melatih anggota kelompok dapat bertenggang rasa terhadap teman sebayanya. Ketiga, dapat mengembangkan bakat dan minat masing-masing anggota kelompok. Keempat, mengentaskan permasalahan-permasalahan anggota kelompok. ${ }^{12}$ Menurut Hansen dalam Taufik bahwa "seorang individu haruslah mempunyai ego yang sehat dan ego yang kuat."13 Manusia lahir ke dunia dilengkapi kemampuan untuk menampung berbagai perangsang dari luar, kemampuan untuk merangsang tersebut terletak pada fungsi ego seseorang.

Untuk itu dalam mengatasi resiliensi diri rendah menggunakan pendekatan ego dalam konseling kelompok yang harus diketahui yaitu pertama adanya sikap keyakinan yang ditunjukkan saat kita merasa cukup tahu dan menyimpulkan bahwa kita telah mencapai suatu kebenaran. Kedua, memiliki sikap kemandirian dan kekuasaan atas dirinya sendiri untuk melakukan sesuatuyang diinginkan sepanjang tidak melanggar kepentingan orang lain dengan kata lain manusia tidak berada di bawah tekanan dan tindakan yang merendahkan martabat sebagai manusia. Ketiga, bersikap inisiatif dengan mampu memutuskan dan melakukan sesuatu yang benar tanpa harus diberi tahu, mampu menemukan apa yang seahrusnya dikerjakan terhadap sesuatu yang ada di sekitar. Keempat, memiliki konten tertentu yang bisa dikembangkan dan mampu mencetak prestas terhadap konten yang dimiliki dan yang kelima memiliki identitas diri, yang mana adanya kesadaran kita untuk menempatkan diri dan memberi arti pada dirinya sebagai seseorang pribadi yang unik. Identitas diri berupa fisik, keyakinan, tujuan, harapan, prinsip yang setiap individu itu berbeda. ${ }^{14}$

Berdasarkan hasil penelitrian diatas dapat diketahui bahwa pendekatan ego dapat menjadi alternatif bagi guru BK untuk meningkatkan resiliensi diri siswa yang rendah, karena proses yang dilakukan dalam pendekatan ego sangat membantu bagi siswa. Disini ego yang mucul sebagai pola untuk mengambil keputusan ketika dihadapkan dengan masalah apakah ego yang muncul akan berpengaruh terhadap resiliensi diri tersebut. Resiliensi diri yang rendah muncul diakibatkan oleh ego yang tidak berfungsi dengan baik, baik untuk menggerakkan dirinya dalam memenuhi kebutuhannya maupun meraih keinginannya.

${ }^{12}$ Dewa Ketut Sukardi, Pengantar Pelaksanaan Program Bimbingan dan Konseling di Sekolah, (Jakarta: PT. Rineka Cipta, 2002), hal 49-50.

${ }^{13}$ Taufik, Model..., hal. 66.

${ }^{14}$ Desmita, Psikologi Perkembangan..., hal 230-232. 


\section{Penutup}

Berdasarkan hasil penelitian yang telah dilaksanakan dapat ditarik kesimpulan bahwa hasil pretest dengan jumlah sampel 10 orang sebelum diberikan perlakuan konseling kelompok dengan pendekatan ego, meannya adalah 135,30 yang mana ini adalah rata-rata resiliensi diri siswa sebelum diberikan perlakuan dan rata-rata nilai ini tergolong rendah. Hasil postest dengan jumlah sampel 10 orang setelah diberikan perlakuan konseling kelompok dengan pemdekatan ego, meannya adalah 136,10 yang mana ini adalah rata-rata resiliensi diri siswa setelah diberikan perlakuan dan nilai ini tergolong tinggi. Terdapat perbedaan antara nilai pretest dengan nilai posttest, pernyataan ini didukung dengan dibuktikan dari hasil asymp sig (2-tailed) diperoleh nilai sebesar $(0,005)$ yang berarti lebih kecil dari alpha $(0,05)$. Maka dapat dikatakan Ha diterima zhitung 2,807 > dari ztabel 1,833 yaitu pada taraf signifikansi 0,05 , maka dapat dikatakan $\mathrm{Ha}$ diterima dan $\mathrm{H} 0$ ditolak, artinya terdapat peningkatan resiliensi diri siswa untuk pretest dan postest melalui layanan konseling kelompok dengan pendekatan ego.

Berdasarkan hasil penelitian di SMA N 2 Padang Panjang, maka peneliti memberikan beberapa rekomendasi, diantaranya kepada guru BK agar lebih meningkatkan lagi pelaksanaan layanan konseling kelompok dengan pendekatan ego secara baik dan berkesinambungan, agar resiliensi diri siswa dapat berfungsi dengan baik. Khususnya siswa di SMA N 2 Padang Panjang. Selain itu, siswa diharapkan agar senantiasa bersikap proaktif dalam mengikuti kegiatan layanan untuk mengentaskan permasalahan yang dialami, sehingga Guru BK dapat memanfaatkan layanan konseling kelompok dengan pendekatan ego untuk meningkatkan resiliensi diri.

\section{Daftar pustaka}

Achmad, Juntika Nurihsan. Bimbingan dan Konseling dalam Berbagai Latar Kehidupan. Bandung: PT. Refika Aditama, . 2006.

Arikunto, Suharsimi. Manajemen Penelitian. Jakarta: PT. Rineka Cipta, 2002.

Azwar, Saifuddin. Reliabilitas dan Validitas Edisi IV. Yogyakarta: Pustaka Pelajar, 2012.

Candra, Silvia. Resiliensi.www.rumahbelajarpsikologi.com/index2.php?option= comcontentdopdf $=1 \mathrm{id}=139$. (diakses 06 April 2019).

Corey, Gerald. Teori dan Praktek Konseling dan Psikoterapi, Terj. E. Koswara, Theory and

Practice of Counseling and Psychotherapy. Bandung: PT. Refika Aditama, 2019.

Desmita, Psikologi Perkembangan. Bandung: PT. Remaja Rosda Karya, 2006. 
Dewi, Ayunda Mayasari. Pengaruh Layanan Bimbingan Kelompok terhadap Peningkatan Resiliensi Siswa. Skripsi Pendidikan Bimbingan dan Konseling di IKIP Veteran Semarang.

Edi, Kurnanto. Konseling Kelompok. Bandung: Alfabeta, 2014.

Elida, Prayitno. Koseling Kelompok. Padang: FIP UNP, 2007. Etheses.uinmalang.ac.id www. Kajian Teori Resiliensi (Diakses 14 Desember 2018).

Yusri, F. 2014. Pemanfaatan Model-model dalam Pelayanan Konseling untuk Membentuk Generasi Berkarakter Bebas Narkoba. Jurnal Konseling dan Pendidikan.

Harlock, B. Elizabeth, Psikologi Perkembangan, Jakarta: Erlangga, 1991 http://dansite. wordpress.com /2009/03/28/ pengertian-efektifitas, (Diakses 17 Desember 2018).

Hendriani, W. (2018). Resiliensi psikologis: sebuah pengantar. Kencana.

Nurkancana, Wayan. Pemahaman Individu. Surabaya: Usaha Nasional, 1993.Obsevasi dan Wawancara dengan guru Bk, 27 Agustus 2018.

Prayitno dkk. Dasar-dasar Bimbingan dan Konseling. Jakarta: Rineka Cipta, 1999.

Prayitno. Seri Kegiatan Pendukung Konseling L1-L9. Padang: UNP, 2004.

Prayitno \& Erman Amti. Dasar-dasar Bimbingan dan Konseling. Jakarta: Rineka Cipta, 2004.

Sudaryono. (2007). Resiliensi dan Locus of Control Guru dan Staff Sekolah Pasca Gempa,

(PDF), Fakultas Psikologi Airlangga Surabaya. www.google.co.id/url_jurnal_re siliensi_dan_locus_control_guru_dan_staff_sekolah_pasca_gempa\&staf f.uny.ac.id, (diakses 12 Januari 2019).

Sukardi. Metodologi Penelitian Pendidikan (Kompetensi dan Praktiknya). Jakarta: Bumi Aksara, 2010.

Sukardi, Dewa Ketut. Proses Bimbingan dan Konseling di Sekolah. Jakarta: PT. Rineka Cipta, 2008.

Suryabrata, Sumadi. Metodologi Penelitian. Jakarta: PT Raja Grafindo, 2004.

Taufik. Model-model Konseling. Padang: FKIP UNP, 2009.

Tohirin. Bimbingan dan Konseling di Sekolah dan Madrasah. Jakarta: Raja Grafindo Persada, 2007.

Willis, S. Sofyan. Konseling Individual Teori dan Praktek. Bandung: CV Alfabeta, 2007. 
236 | Islamic Counseling: Jurnal Bimbingan dan Konseling Islam, Vol. 4, No. 2, 2020

Yusri, Fadhilla. Intrumen non Tes dalam Konseling, (Bukittinggi: IAIN Bukittinggi), 2015.

Yusuf, A. Muri. Metodologi Penelitian. Padang: UNP, 2005. 